International Review of Social History 44 (1999), pp. 367-394

(C) 1999 Internationaal Instituut voor Sociale Geschiedenis

\title{
Tides of Migration, Currents of History: The State, Economy, and the Transatlantic Movement of Labor in the Nineteenth and Twentieth Centuries*
}

\author{
CARL STRIKWERDA
}

Summary: International migration has flowed and ebbed in two long waves over the last two hundred years. The major determinants of international migration have been the economy and the state. The economic forces impinging on migration are demography, technology, the level of wages, and geographical proximity, transportation, and communications. The state is the confluence of social and political forces within countries which define, encourage or curtail, and regulate movement across borders. The lesson of the nineteenth-century migration system is that states created it or allowed it to happen. They also always had the power to end it, and they eventually did. The huge break in the history of migration which accompanied the era of the world wars points to the decisive power of the state to control migration and, by extension, the direction of economic development itself. The present article reviews the major phases of the history of modern migration in order to put the present crossroads in perspective.

\section{INTRODUCTION}

At the close of the twentieth century and the dawn of the twenty-first, we stand at what might be a crossroads of economic and political development. The end of the Cold War has released a large part of the world from a long burden of closed borders and concern with military security. The unprecedented globalization of many national economies and the dramatic rise of

\footnotetext{
* The author would like in particular to thank the organizers of the Amsterdam Colloquium on Migration in October and November 1997: Patrick Fridenson, Marcel van der Linden, Jan Lucassen, and Louise Tilly. Other participants in the colloquium who provided useful criticisms were Thomas Dublin, Donna Gabaccia, René Gallissot, Dirk Hoerder, Earl Lewis, Leo Lucassen, Leslie Page Moch, Elisabetta Vezzosi and Aristide Zolberg. Members of the Globalization Seminar at the University of Kansas also provided useful criticisms: David Burress, Joe Harrington, Joane Nagel, and David Smith. Research for this article was supported by the American Philosophical Society and the German Marshall Fund of the United States. Portions of this article appeared earlier as part of Carl Strikwerda and Camille Guerin-Gonzales, "Labor, Migration, and Politics", in Camille Guerin-Gonzales and Carl Strikwerda (eds), The Politics of Immigrant Workers: Labor Activism and Migration in the World Economy since I830 (New York, 1998), pp. 3-52.
} 
new economic powers in East Asia make the great gulf between the developed world and Africa, the rest of Asia outside the Pacific Rim, and much of Latin America more obvious than ever before. What lies ahead? One vision of the future suggests that economic globalization will produce genuine convergence between societies. Capital, goods, and labor will flow more freely, and governments will adopt increasingly similar methods of economic management - and increasingly less economic management. ${ }^{r}$ Societies as a whole may resemble each other in this "McWorld", as Benjamin Barber has described it. ${ }^{2}$ According to this vision of the future, the current wave of globalization is a profoundly new phenomenon which has grown inevitably out of the industrialization of the last I5O years. Even moderate exponents of this globalization thesis suggest that in the process of economic growth governments are losing control over economic processes which now increasingly run on their own - despite governments having helped set economic globalization in motion. ${ }^{3}$ In a second vision of the future, less optimistic observers predict that the economic gulf between rich and poor nations and the social upheaval accompanying economic change will lead to tremendous conflict. This conflict may be simultaneously cultural, economic, and political - "Jihad", the "wrath of nations", or the "clash of civilizations", according to different observers. ${ }^{4}$ The crisis which hit east Asia in the late I990s, the recent waves of nationalism and ethnic and religious conflict, and the pressure for protectionism and tighter border controls suggest that the world is still a unstable place in which economic tensions can have explosive consequences. Managing the economic connections between nations, in other words, may be one of the keys to world stability in the next century. ${ }^{5}$

Perhaps the most politically controversial of economic connections between countries has always been the movement of labor. Migration around the globe at present may already be at one of its all-time peaks and appears to be still rising. Some estimates of the total number of migrants working outside their home country go as high as 120 million. ${ }^{6}$ In the

I. Ali El-Agraa, "The Theory of Economic Integration", in El-Agraa (ed.), International Economic Integration (London, 1982); Peter Robson, The Economics of International Integration (London, 1980); World Bank, Global Economic Prospects and the Developing Countries 1996 (Washington DC, 1996). Suzanne Berger and Ronald Dore (eds), National Diversity and Global Capitalism (Ithaca, NY, 1996) provide a useful critical overview of the so-called "convergence" thesis.

2. Benjamin Barber, Jihad vs. McWorld (New York, 1995).

3. Saskia Sassen, Losing Control? Sovereignty in an Age of Globalization (New York, 1996).

4. Samuel P. Huntington, The Clash of Civilizations and the Remaking of World Order (New York, 1996); William Pfaff, The Wrath of Nations: Civilization and the Furies of Nationalism (New York, 1993). Barber presents both the optimistic view of convergence and the pessimistic view in reactions against modernization, but he implies the clash between the two will lead to instability.

5. David Henderson, "International Economic Integration: Progress, Prospects, and Implications", International Affairs, 68 (1992), pp. 633-653.

6. United Nations, Population Fund Annual Report 1993 (New York, I993); W.R. Böhning and Nara Oishi, "Is International Economic Migration Spreading?", International Migration Review, 
globalization scenario, if the less developed countries make a large leap toward industrialization in the next century while national barriers continue to weaken, one result could be a huge increase in labor migration. Pessimistic observers fear that migration will create political conflict, as poor immigrants destabilize rich countries. History seems to predict that large international waves of migration accompany economic development. Britain, France, Germany, Italy, and the US all depended on international migration as a crucial lever, either to export their unemployment or to attract labor, and, in some cases such as Germany, first the one policy, then the other. ${ }^{7}$ Even Japan and Russia, the two clearest examples of what could be seen as internal economic development, relied on migration more than is usually realized. About 600,00o laborers left Meiji Japan in the late nineteenth and early twentieth centuries, while between I9I5 and 1940, almost a million Koreans went temporarily to Japan and of these, 400,000 migrated permanently. ${ }^{8}$ Under Soviet rule, an estimated seven million ethnic Russians migrated to what we can now see as international borders in the Baltic lands, the Ukraine, and central Asia. ${ }^{9}$ In the nineteenth century, the importance of migration, too, went beyond the movement of Europeans to the United States and other areas of what eventually became predominantly European settlement such as Argentina and Australia. Investment in Asia, Africa, and the western hemisphere often depended on migration. Millions of Chinese,

29 (1993), pp. 794-799. Peter Stalker, The Work of Strangers: A Survey of International Labour Migration (Geneva, 1994), p. 3, gives a slightly lower estimate of about Ioo million.

7. Klaus Bade, "German Emigration to the United States and Continental Immigration to Germany in the Late Nineteenth and Early Twentieth Centuries", and Robert Lewis Mikkelsen, "Immigrants in Politics: Poles, Germans, and the Social Democratic Party of Milwaukee"; both in Dirk Hoerder (ed.), Labor Migration in the Atlantic Economies: The European and North American Working Classes during the Period of Industrialization (Westport, CT and London, 1985), pp. II7-I42, 277-295; Ewa Morawska, "Labor Migration of Poles in the Atlantic World Economy, I880-1914", in Dirk Hoerder and Leslie Page Moch (eds), European Migrants: Global and Local Perspectives (Boston, MA, 1996), pp. I70-208. See also Karl Obermann and Heinz-Peter Thummler, "Allemagne: Les grands mouvements de l'émigration allemande vers les États-Unis d'Amérique au XIXe siècle”, Wolfgang Kollman and Peter Marschalck, "Allemagne: German Overseas Emigration since I8I5", and Celina Bobinska and Adam Galos, "Pologne: Poland: Land of Mass Emigration (XIXth and XXth Centuries)"; all in Les migrations internationales de la fin du ХVIIIe siècle à nos jours (Paris, 1980), pp. 407-502; Carl Solberg, "Mass Migration in Argentina, I870-1970", in William McNeill and Ruth Adams (eds), Human Migration: Patterns and Policies (Bloomington, IN and London, 1978). See also Magnus Mörner, Adventurers and Proletarians: The Story of Migrants in Latin America (Pittsburgh, PA and Paris, 1985), pp. 35-66.

8. Mitsuru Shimpo, "Indentured Migrants from Japan", in Robin Cohen (ed.), The Cambridge Survey of World Migration (Cambridge, 1995), pp. 48-50; David Northrup, Indentured Labor in the Age of Imperialism, I834-1922 (Cambridge, 1995), pp. 72-74; Helmut Loiskandl, "Illegal Migrant Workers in Japan”, in Cohen, Cambridge Survey, p. 372; Saburo Ienaga, The Pacific War I93I-I945 (New York, I978), pp. I56-I59; Hideo Totsuka, "Japon: Koreans in Pre-War Japan”, in Les migrations internationales.

9. Hélène Carrère d'Encausse, Decline of an Empire: The Soviet Socialist Republics in Revolt (New York, I979), pp. 70-77. 


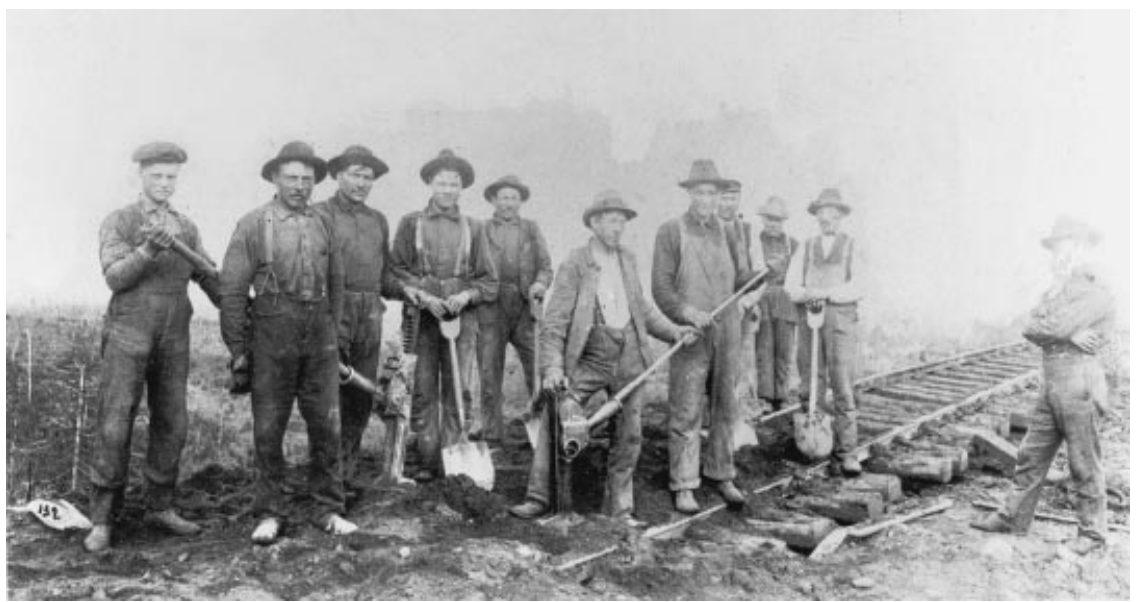

Figure I. Finnish miners laying railway track, ca. I9IOs. Industrialization created a large demand for immigrant labor in both mining and transportation.

Tyomies Society Photo Collection, \#447, Immigration History Research Center, Minnesota

Filipino, and Indian workers moved around the globe, often as indentured laborers. ${ }^{\text {Io }}$ Given this central importance of migration to what was the first era of global economic growth, it is crucial to look at this great past movement of labor in light of the present crossroads in international political economy. What were the critical underpinnings of migration in the past? Could anything like nineteenth-century migration happen again?

This article will argue that most observers of the present juncture in world affairs underestimate the critical importance of the state in determining migration and indeed in determining economic integration itself. ${ }^{I I}$ The

IO. Kay Saunders (ed.), Indentured Labour in the British Empire: I834-I920 (London, 1984); A.J.H. Latham, "Southeast Asia: A Preliminary Survey, I80o-1914", in Ira Glazier and Luigi De Rosa (eds), Migration Across Time and Nations: Population Mobility in Historical Contexts (New York, 1986); Hugh Tinker, "Into Servitude: Indian Labour in the Sugar Industry, I833-1970", and Pieter Emmer, "The Importation of British Indians into Surinam (Dutch Guiana), I873-1916"; both in Shula Marks and Peter Richardson (eds), International Labour Migration: Historical Perspectives (London, 1984); Yen Ching-Hwang, Coolies and Mandarins: China's Protection of Overseas Chinese during the Late Ch"ing Period (I85I-1922) (Singapore, 1985), and P.C. Campbell, Chinese Coolie Emigration to Countries within the British Empire (London, 1923); Surendra Bhana, "Indentured Labor Migration: Indian Migrants to Natal, South Africa, I860-1902", in Guerin-Gonzales and Strikwerda, Politics of Immigrant Workers; Surendra Bhana and J.B. Brain, Setting Down Roots: Indian Migrants in South Africa, I860-I9II (Johannesburg, I990).

II. Wayne A. Cornelis, Philip Martin, and James F. Hollifield, "Introduction: The Ambivalent Quest for Immigration Control", in Cornelis, et al. (eds), Controlling Immigration: A Global Perspective (Stanford, CA, 1994) argue that industrial, host states are increasingly less able to control migration. In fact, the essays in their own edited volume suggest the reverse. Hollifield himself admits France has controlled immigration, albeit at a high cost: "Immigration and Republicanism in France", in Cornelis, Controlling Immigration, pp. 166-169. Patrick Weil points out 
present wave of globalization is not as unprecedented as it appears, nor are either its consequences or its continuation inevitable. In many ways, globalization was proceeding faster in 1914 than it is today. As the Depression and two world wars indicate, increasing economic integration is not inevitably the result of industrialization. International migration has flowed and ebbed in two long waves over the last two hundred years. The huge break in the history of migration which accompanied the era of the world wars points to the decisive power of the state to control migration and, by extension, the direction of economic development itself. The power of the state to control migration means as well that the hordes of poor can actually be kept out of rich nations or channeled in certain directions more easily than the pessimistic scenario suggests. The economic and human costs of controlling migration may be large, but states have imposed them in the past, and they are likely to impose them again. International migration is thus always an economic and political phenomenon. The major determinants of international migration have been the economy and the state. The economic forces impinging on migration are demography, technology, the level of wages, and access - geographical proximity, transportation, and communications. The state is the confluence of social and political forces within countries which define, encourage or curtail, and regulate movement across borders. The interaction between these two factors creates the complexities of international migration. ${ }^{\mathrm{I}}$ This article will lay out these critical definitions, and then review the major phases of the history of modern migration in order to put the present crossroads in perspective.

In economic terms, the exact layering of state boundaries over the paths migrants take can be seen as incidental. In other words, if states are unable or unwilling to use their borders and legal powers as means of control, people often move without a great deal of attention to boundaries. The same economic forces encouraging or compelling immigrants to move across international borders have also pushed migrants to move within countries, although the relationship between the two kinds of migration is complex. Most countries which have experienced large-scale out-migration have experienced at the same time large-scale migration within their borders. The massive movement of over fifty million Europeans overseas before World War I was part of a still larger migration within Europe from countryside

Hollifield's inconsistency: "Commentary", in Cornelis, Controlling Immigration, pp. I82-183. Zig Layton-Henry states that British controls are "horrendously tight": Zig Layton-Henry, "Britain: The Would-be Zero-Immigration Country", in Cornelis, Controlling Immigration, p. 293.

I2. Aristide Zolberg, "International Migration in Political Perspective" and Elizabeth McLean Petras, "The Global Labor Market in the Modern World-Economy"; both in Mary Kritz, Charles Keely, and Silvano Tomasi (eds), Global Trends in Migration: Theory and Research on International Population Movements (New York, 1983); Saskia Sassen, The Mobility of Labor and Capital (Cambridge, MA, 1988), pp. 26-59. 
to city. ${ }^{13}$ Although international and internal migration often occur simultaneously during times of economic transformation, in terms of size, the two streams of migration sometimes have an inverse relationship: when internal migration slows, international migration increases. Overlying this relationship, however, are long-term shifts within the world economy in which countries become more industrialized. If the demand for labor within a country increases enough that internal migration cannot meet it, international out-migration may cease altogether and be replaced by migrants coming into the country from outside.

More typically, however, the state has been just as crucial in determining international migration as economic forces. Indeed, what differentiates international migration from migration within states is the overwhelmingly greater role of the state. The state defines immigration as we perceive it today. The "immigrant", the person who moves from one nation state to another, is an artifact of modern history. ${ }^{\mathrm{I}}$ Far back in the recorded past, large groups have moved from place to place in search of work. But only the rise of state bureaucracies that confer citizenship and police national borders has made it possible to demarcate immigrants as a group. Even when immigration was controlled in Europe before the nineteenth century, it was usually towns or guilds, not national governments, that determined whether "foreigners" could work. ${ }^{15}$ Nor is it even true that proportionately more immigration has occurred in the industrial or modern nation state than in earlier forms of society. Huge numbers of people moved over large distances in pre-industrial Europe and China. ${ }^{16}$ In the nineteenth century, however, modern governments acquired the ability to keep track of each resident within their territories. As one nineteenth-century writer put it, "The entire surface of Europe, to the extent the land can be controlled, is divided up into sovereign states. ${ }^{\text {117 }}$ Immigrants, therefore, could be clearly identified as different from citizens. In I85I, the French census for the first time counted French citizens and foreigners separately. ${ }^{18}$ At the same time,

13. Leslie Page Moch, Moving Europeans: Migration in Western Europe since I650 (Bloomington, IN, 1992), pp. IO2-160.

I4. This section draws on Carl Strikwerda and Camille Guerin-Gonzales, "Labor, Migration, and

Politics", in Guerin-Gonzales and Strikwerda, Politics of Immigrant Workers, pp. I2-I8.

15. William McNeill, "Human Migration: An Historical Overview", in McNeill and Adams, Human Migration; Mack Walker, German Home Towns: Community, State, and General Estate, I648-I87I (Ithaca, NY and London, I97I), pp. 73-IO7.

16. McNeill, "Human Migration", in McNeill and Adams, Human Migration; Jan deVries, European Urbanization, 1500-I800 (Cambridge, MA, 1984), p. 213; and James Lee, "Migration and Expansion in Chinese History", in McNeill and Adams, Human Migration.

17. J.-L. Klüber, Droit des gens modernes de l'Europe, edited, annotated, and completed by A. Ott, 2nd ed. (Paris, I874), p. 44.

I8. Gérard Noiriel, Population, immigration, et identité en France: XIXe-XXe siècle (Paris, 1992), pp. 92-I2I. 
modern nationalism divided some groups and merged others. ${ }^{\text {I9 }}$ The annexation of Polish areas by Prussia in the eighteenth century meant that, in the early twentieth century, most "Poles" in Ruhr mining towns were German citizens and could not be controlled as easily as the Poles from Austrianand Russian-annexed areas who entered Germany to work as non-citizens. ${ }^{20}$

If states are so important for migration, one might naturally ask why there is no "international regime" of labor, that is, no governing set of supra-national institutions or practices which restrict states' control of migration. The 1952 Geneva Convention on Refugees is the nearest thing we have to an international set of rules on migration, but it says virtually nothing about labor migration which has been the dominant mode of migration among states. ${ }^{21}$ Even with the enormous rise in refugees during the late twentieth century, most estimates are that migrants seeking employment still outnumber refugees almost two to one. ${ }^{22}$ Despite the lack of an "international regime" of migration, I would argue that the shifting tides of migration have been profoundly affected by the "international regimes" which the Western world has known over the last two centuries in other areas of international relations such as trade and diplomacy. ${ }^{23} \mathrm{~A}$ "regime", which is admittedly a heavily-debated concept, can be a set of accepted practices which restrain behavior in what is otherwise an "anarchical society". ${ }^{24}$ States are and remain sovereign, that is, they recognize no higher legal or political authority over them, but they accept certain guidelines out of self-interest, moral pressure, or a desire to ensure their legitimacy with their own citizens. The First World War marks a sharp break in the history

19. Carl Strikwerda, "Nationalism, Ethnicity, and Social Movements", Brood en Rozen, I (1997), pp. II-23.

20. John J. Kulczycki, "The Prussian Authorities and the Poles of the Ruhr", International History Review, 8 (1986), p. 599.

2I. W.R. Bohning lists four distinct types of foreign migrants: (I) refugees or persons who leave their own country because of a well-founded fear of persecution by reasons of race, religion, nationality, political association or social grouping; (2) economically active persons for the purpose of employment; (3) a residual category such as pilgrims, ministers of religion, diplomatic and unassimilated personnel, students, volunteers sponsored publicly or by charity, retired or other persons living entirely on their own means; and (4) a derivative category, namely the parents, spouses, siblings and children of some or all of the preceding three groups. W.R. Böhning, "Elements of a Theory of International Economic Migration to Industrial Nation States”, in Kritz, Keely, and Tomasi, Global Trends in Migration, pp. 28-29. Workers can be considered as the largest subgroup within Böhning's second category of those who migrate as economically active people seeking employment. On refugees and the 1952 Geneva Convention, Michael Marrus, The Unwanted: Refugees in the Twentieth Century (New York, 1989); Gerard Noiriel, La Tyrannie du national (Paris, 1991).

22. Böhning and Oishi, "Is International Economic Migration Spreading?", pp. 794-797.

23. Aristide R. Zolberg, "Labour Migration and International Economic Regimes: Bretton Woods and After", in Zolberg, International Migration Systems: A Global Approach (Oxford, 1992), pp. 316-319.

24. Stephen D. Krasner, "Structural Causes and Regime Consequences: Regimes as Intervening Variables”, International Organization, 36 (1982), pp. 185-206; Hedley Bull, The Anarchical Society: A Study of Order in World Politics (New York, 1977). 
of migration, one which the immense power of economic globalization has still not undone. As powerful as today's multinational corporations are, they have had a relatively small impact on lowering the barriers to migration. Despite the contemporary economic boom, I would argue, migration in the future will almost certainly never flow as freely as it did a century ago, unless a major - and highly improbable - transformation of state policy makes it possible. The combined power of interest groups within states opposed to immigration is strong enough, in other words, to limit the impact of globalization in the twenty-first century. Goods and capital may increasingly move with little regard for borders. By contrast, people will still need to respect borders, and this check on complete integration may itself slow the impact of the movement of goods and capital.

\section{THE NEW REGIME: FROM FREE TRADE TO THE GREAT MIGRATION}

To understand how the nineteenth-century migration system arose and which of its features might re-emerge, we must begin in a curious place. The Concert of Europe, the cooperation between the largely conservative powers of Europe which began at the Congress of Vienna after the Napoleonic Wars, is generally seen as one of the backward phases of modern history. Paul Schroeder, however, has argued that the tradition of political stability and diplomatic consultation which the Concert began represented a fundamental change in international politics. ${ }^{25}$ Dynastic and mercantilistic wars, balance of power politics, and partitions disappeared, some completely, some for almost a century. Just as important, whereas mercantilistic doctrine had said that subjects' economic welfare was best served by an economically powerful state, the Congress of Vienna allowed and even encouraged states to see themselves as economic units which included their citizens' own well-being. As reactionary as many rulers could still be in political terms, the French Revolution and Napoleonic Wars taught them at least to respect the power of their own citizens and to realize that allowing citizens to better themselves might in the long run help their states. The economic resources of a society were no longer simply the tool-kit for making war. Instead, states came increasingly to see the betterment of society's economic wellbeing as strengthening the state's legitimacy. As Schroeder puts it:

Trade and economic activity became more important in international affairs than ever; the old calculations of state power strictly on the basis of revenues, population, territory, strategic frontiers, and armed forces expanded to include

25. Paul Schroeder, "The 19th Century International System: Changes in Structure", World Politics, 39 (1986), pp. I-26. 
economic and technological development, commerce, natural resources, and political stability. ${ }^{26}$

The Congess also outlawed the slave trade and, although it took some decades to make this abolition truly effective, this, too, had enormous consequences for migration.

I would build on Schroeder's argument and argue that the significant degree of international cooperation, free trade, and economic integration which arose in the nineteenth century was only possible because of this diplomatic transformation, which created the first modern "international regime". It was when continental European rulers decided that quality of skills and economic freedoms were more important than simple population numbers and quantity of tax revenue that they eased up on the restrictions on migration. ${ }^{27}$ In turn, it was only because of the stability after the Congress of Vienna that mid-nineteenth-century liberal reformers could argue that freer economic ties among states would benefit all societies. The belief that free trade between countries could act as a force for peace may be traced to numerous European sources: the British novelist Defoe, the French bishop Fenélon, and the German philosopher Kant whose essay "On Perpetual Peace" is perhaps its finest expression. What is remarkable about the mid-nineteenth century is that a significant part of the Western world for the first time tried to make this ideal a part of practical policy. In doing so, states actually reached back in part to an even older Western tradition. In the medieval period, before the early modern rise of monarchical centralization, merchants of various lands had evolved their own private international law - often called "law merchant" or "lex mercatoria" - which allowed a surprising freedom of movement for purposes of trade. Under the "regimes de paix" which governed trade fairs, for example, subjects of almost any polity could move freely in order to sell goods for a limited time. ${ }^{28}$ In the mid-nineteenth century, almost all western European states repudiated centuries of protectionism which had intervened since the medieval period and actually tried to adopt free trade on a vastly wider international scale. Britain dropped its protectionist Corn Laws in I846. In I860, Britain and France signed the landmark Cobden-Chevalier treaty lowering their tariffs. Although it is often argued that free trade was a kind of British hegemony, it is better to see the movement as a European one. ${ }^{29}$ Prussia and the other German states, Belgium, Denmark, and most of western Europe dropped

26. Paul Schroeder, The Transformation of European Politics, 1763-1848 (Oxford, 1994), p. 579.

27. Walker, Germany, pp. 63-87.

28. W.A. Bewes, The Romance of the Law Merchant (London, 1923).

29. Bernard Semmel, Free Trade Imperialism (New York, 1978); Pierre Ayçoberry, "Freihandelsbewegungen in Deutschland und Frankreich in den I840er und I85oer Jahren", in Dieter Langewiesche (ed.), Liberalismus im I9. Jahrhundert: Deutschland im europäischen Vergleich (Göttingen, 1988), pp. 298-299; Charles Kindleberger, "The Rise of Free Trade in Western Europe, I820 to I875", Journal of Economic History, 35 (I975), p. 55. 
tariffs, eased laws on international trade, and promoted freedom of navigation. Still more important, the era of free trade was about more than lowering tariffs. International agreements on postal arrangements, undersea cables, maritime commerce, and financial transactions all grew out of the effort to connect the economies of various states. Without these essential avenues linking societies, the great migrations of the nineteenth century would have been much smaller, less responsive to changing economic conditions, and more conflict-ridden. States never gave up the right to expel foreigners for a variety of offenses, but by comparison with earlier centuries and the later decades of the twentieth century, the relative freedom of labor to move is striking. The one major exception was German restrictions on Polish workers from outside the Reich, but even here the demand for labor eventually forced the Germans to encourage Poles to come..$^{3 \circ}$

The result was the greatest international migration in world history. During the I840s the migration of Europeans overseas finally surpassed forced African migration to the New World and the migration of Asians within Asia. ${ }^{31}$ As controls on land and personal mobility were eased and then disappeared, migrants could move along roads, railways, and steamship lines created by the increasingly free flow of goods in the mid-nineteenth century. ${ }^{32}$ European migration to the Americas averaged 30,000-40,000 annually in the I820s and I830s. By the I850s, emigration averaged over 250,000. While the desperate hunger and poverty of the I840s first caused migration to increase, it was striking that migration continued to be high from the I850s to I880s. ${ }^{33}$ Between 1860 and I9I4, some fifty-two million Europeans moved to the Western hemisphere, Asia, or Oceania. ${ }^{34}$ This number is all the more astonishing when one realizes that the number of Europeans moving to cities within Europe during the same period was even larger, perhaps as large as eighty million. In the process, a Europeancentered and European-controlled migration system superseded and absorbed other, older systems of migration based on Asians or North Africans moving between lands around the Indian Ocean, the South China

30. Wilhelm Bohmert, "Die ausländischen Arbeiter in Deutschland", Der Arbeiterfreund, 5I (1913), pp. 17-46; J. Nichtweiss, Die ausländischen Saisonarbeiter in der Landwirtschaft der ostlichen und mittleren Gebiete des Deutschen Reiches I890-I9I4 (Berlin, 1959), pp. I47-208.

3I. D. Eltis, "Free and Coerced Transatlantic Migrations: Some Comparisons", American Historical Review, 88 (1983), pp. 25I-289; Latham, "Southeast Asia", in Glazier and De Rosa, Migration Across Time and Nations, pp. II-I3.

32. Jerome Blum, The End of the Old Order in Rural Europe (Princeton, NJ, I978), pp. 377-44I; Josef Barton, Peasants and Strangers: Italians, Rumanians, and Slovaks in an American City, I890I950 (Cambridge, MA, 1975), p. 28.

33. Moch, Moving Europeans, p. I47; Walter Nugent, Crossings: The Great Transatlantic Migrations, I870-I9I4 (Bloomington, IN, I992), pp. 29-3I.

34. André Armengaud, "Population in Europe, I700-1914", in Carlo Cipolla (ed.), The Fontana Economic History of Europe, vol. 3, The Industrial Revolution, I700-I9I4 (New York, 1976). 
Sea, and the Middle East. Remittances from migrants represented a huge capital influx into underdeveloped areas, while competition for labor in emigration-prone regions drove up wages..$^{35}$ Equally critical to understanding the uniqueness of the nineteenth century is the fluidity of transportation and communications. A "transportation revolution" occurred in which steam-powered, iron and steel ships lowered the costs of moving both goods and people. ${ }^{36}$ By 1900, certain groups of workers were even able to time their migrations according to changing wages and unemployment in Europe and the western hemisphere. By the years right before World War I, Italian harvest workers and English housepainters were just two of a number of immigrant groups who migrated back and forth between Europe and North or South America each year. Between 1900 and 1910, approximately onetenth of the Italians entering the United States had been there before. ${ }^{37}$ It was, in part, this fluidity of travel and news that allowed Asian workers to be added to the movement of Europeans and create the closest approximation to a global labor market that we have ever seen. Indenture, their own preference to return, and racism in host societies combined to make Indian and Chinese laborers a huge circulating workforce. While some thirty million Indians and Chinese may have left their homelands between I834 and 1932 - the vast majority between I860 and I9I4 - perhaps only one-fifth, six million, permanently migrated. ${ }^{38}$ The sheer size of the Asian migration in this period, however, questions the argument of many observers who believe that the late twentieth century "represents a sharp

35. Morawska, "Labor Migrations of Poles in the Atlantic World Economy".

36. E. Levasseur, "Ports et marine de la France", Revue économique internationale, (juillet, I9II); Kurt Winterfeld, Die nordwesteuropäischen Welthafen (Berlin, 1903); P.N. Davies, "British Shipping and World Trade", pp. 73-77 and L.U. Scholl, "Shipping in Germany", pp. 193-205; both in Tsunehiko Yui and Keiichiro Nakagawa (eds), Business History of Shipping (International Conference on Business History) (Tokyo, 1984).

37. Frank Thistlethwaite, "Migration from Europe Overseas in the Nineteenth and Twentieth Centuries", in Herbert Moller (ed.), Population Movements in Modern European History (Boston, MA, 1964), pp. 75-77; Edmond Ronse, L'émigration saisonnière belge (Ghent, 1913), pp. 23-27. In addition, perhaps as many as one-third of those who entered the United States during the nineteenth century left again. See also J.D. Gould, "European Inter-Continental Emigration - The Road Home: Return Migration from the USA", Journal of European Economic History, 9 (1980), pp. 4I-I22, and Dirk Hoerder, "Immigration and the Working Class: The Remigration Factor", International Labor and Working Class History, 2I (1982), pp. 28-4I. On definitions of circular as opposed to other kinds of migration, Charles Tilly, "Migration in Modern European History", in McNeill and Adams, Human Migration.

38. Latham, "Southeast Asia", in Glazier and De Rosa, Migration Across Time and Nations, p. II, using the estimates of Kingsley Davis, The Population of India and Pakistan (Princeton, NJ, 195I). This apparently includes Chinese and Indian migrants within Asia. Estimates of nineteenthcentury Asian-indentured migration vary widely, from as low as twelve million to as high as thirty-seven million; Stalker, Work of Strangers, pp. II-I3. 
break with the past" in bringing migrants from low-income countries into a formerly European and north Atlantic phenomenon. ${ }^{39}$ As Dirk Hoerder has argued, the direction and scale of Asian and African migrations have changed in recent decades, but the participation of Asia and Africa in global patterns of migration itself is not new. ${ }^{40}$

\section{THE PROBLEM OF THE LATE NINETEENTH CENTURY: CHANGE OR CONTINUITY?}

If the system of migration which Western states created in the nineteenth century is the crucial period against which contemporary globalization has to be measured, why has it not more often been seen that way by scholars? Why have many historians, in fact, tried to argue away its uniqueness? The common explanations of the nineteenth-century migration system can be grouped under two major headings. The first argues that migration occurred primarily because of demographic shifts and economic modernization and thus that the role of the state was secondary. The second argues that the nineteenth century saw only a temporary change in underlying restrictionism and protectionism. Both of these views, I believe, underestimate the uniqueness of the nineteenth-century system and thus make it more difficult to assess the role of migration in the current era of globalization.

Scholars who have emphasized the demographic component argue that the great migration was an inevitable transfer of surplus population from heavily populated areas to less populated ones or from areas of poverty and low wages to high-wage areas. ${ }^{4 \mathrm{I}}$ Migrants moved away from the explosive population growth in Europe to the relatively underpopulated societies of the New World and Oceania or from an unindustrialized "periphery" such as southern and eastern Europe into an industrialized core of north-western Europe and the north-eastern United States. Migrants, it is often argued, formed a "reserve army" of surplus unskilled labor, supposedly more subject to unemployment and more malleable by employers. ${ }^{42}$ This view of the nineteenth century is crucial to larger arguments about migration today. Many would see a continuity between late nineteenth-century migration to the industrialized "core" and migration today to developed societies. For the

39. Douglas Massey, "The Social and Economic Origins of Immigration", Annals of the American Academy of Political and Social Science, 510 (1990), p. 62. Massey's source is the classic work: Imre Ferenczi, International Migrations (2 vols) (New York, 1929). It seems clear now that Ferenczi underestimated African and Asian migration in the nineteenth century.

40. Dirk Hoerder, "The Pacific Migration System, I570s to I990s, in Comparative Global Perspective”, Social Science History Association, November 1998.

4I. The following section draws on Strikwerda and Guerin-Gonzales, "Labor, Migration, and Politics", in Guerin-Gonzales and Strikwerda, Politics of Immigrant Workers, pp. 5-7.

42. Gary S. Cross, Immigrant Workers in Industrial France: The Making of a New Working Class (Philadelphia, PA, 1983), p. IO; David Montgomery, The Fall of the House of Labor: The Workplace, the State, and American Labor Activism, I865-1925 (Cambridge, MA, I987), pp. 70-7I. 
contemporary world, Michael Piore has argued that immigrants from less industrialized countries in Latin America, North Africa, and the Middle East act as a kind of reserve labor force for the more developed economies of North America and western Europe. These "birds of passage", as he calls them, come into the industrialized economies when needed, are generally not assimilated into the new societies, and frequently return to their countries of origin when work is difficult to find. ${ }^{43}$

Similarly, scholars have downplayed the unique role of the state in the nineteenth-century system by arguing that "the liberal moment in the history of international migration was extremely short-lived".$^{44}$ By the I88os, if not earlier, all the forces moving toward fewer international economic ties were in place, and the twentieth century of more restricted migration was less a change than simply a working out of long-term trends. Antiimmigrant feeling was often closely tied to opposition to all international ties. ${ }^{45}$ Arguments against imported goods, foreign investments, and multinational companies attracted the support of groups such as the lower middle class and farmers who suffered from the economic cycles and harsh competition in a capitalist system. Nationalist opposition to international economic integration was a convenient way for these groups to express their grievances against social and economic change under the legitimacy of patriotism..$^{46}$ "The government of the United States will, unless the influence of foreigners be curtailed, be ultimately overwhelmed", warned one activist in $1856 .{ }^{47}$ In Australia, New Zealand, Canada, the US, and South Africa, anti-Asian controls profoundly shaped the labor movement and determined the composition of these societies' population. ${ }^{48}$ Restrictions even on

43. Michael Piore, Birds of Passage: Migrant Labor and Industrial Societies (Cambridge, MA, 1979). 44. Zolberg, "Labour Migration and International Economic Regimes", in International Migration Systems, p. 322.

45. John Higham, Strangers in the Land: Patterns of American Nativism, I860-1925 (2nd ed. New York, 197I), pp. 300-324; James Foreman-Peck, "Insiders and Outsiders: The Political Economy of International Migration during the Nineteenth and Twentieth Centuries", in Guerin-Gonzales and Strikwerda, Politics of Immigrant Workers.

46. Philip Nord, Parisian Shopkeepers and the Politics of Resentment (Princeton, NJ, 1986); Michel Tracy, Government and Agriculture in Western Europe, I880-1988 (3rd ed. New York, 1989), pp. 34-35.

47. Samuel Busey, Immigration: Its Evils and Consequences (New York, I856), p. I47.

48. Robert Huttenback, Racism and Empire: White Settlers and Colored Immigrants in the British SelfGoverning Colonies, I830-I9I0 (Ithaca, NY, I976); Raymond Markey, "Race and Organized Labour in a White Settler Colony", in Marcel van der Linden and Jan Lucassen (eds), Racism and the Labour Market: Historical Studies (Bern, I995); Robert Parmet, Labor and Immigration in Industrial America (Boston, MA, 198I), pp. 28-55; Alexander Saxon, The Indispensable Enemy: Labor and the Anti-Chinese Movement in California (Berkeley and Los Angeles, CA, 197I); Edna Bonacich and Lucie Cheng (eds), Labor Migration under Capitalism: Asian Workers in the United States before World War II (Berkeley and Los Angeles, CA, 1984); Gwendolyn Mink, Old Labor and New Immigrants in American Political Development: Union, Party, and State, I875-1920 (Ithaca, NY, I986). 
European immigration commanded a good deal of support in the United States already in the late nineteenth century, and they came close to passage before the First World War. ${ }^{49}$

These arguments minimizing the role of the state in freeing migration and emphasizing the power of anti-immigrant feeling fit well with the prevailing view among historians that the late nineteenth century was characterized by rising economic protectionism and conservative nationalism leading to the catastrophe of the First World War. One economic historian has stated, "In the forty years or so before the First World War, the tendencies that were breaking up the economic unity of Europe were getting stronger in relation to those that made for continuing integration." 50 "From the I870s onwards Europe's political frontiers were becoming, for the first time, also well-defined economic ones", according to a diplomatic historian. ${ }^{\text {SI }}$ Ultimately, the rising tide of conservative nationalism in all areas - tariffs, armaments, controls on migration - combined to produce the inevitable result, a cataclysmic world war which ended the nineteenthcentury system forever.

All the parts of these views, I believe, deserve to be questioned. "Surplus" population is a relative term. People emigrate in response to underemployment, poverty, lack of economic growth, or rising expectations rather than simple population growth. ${ }^{52}$ Countries such as Britain and Sweden experienced huge out-migration in the nineteenth century. Today, these countries have populations twice as large - and import rather than export workers. The same phenomenon has been at work in the post-World-War-II United States. It seems natural that population pressure created migration from Puerto Rico to the United States as the island had a population density more than twelve times that of the mainland. Natural, that is, until one realizes that most Puerto Ricans migrated to New York City, which has a population density more than one hundred times that of their homeland..$^{53}$

The flow of immigrants from non-industrialized areas to the industrialized core, too, is only one way the world economy has determined migration. In the nineteenth century, large numbers of migrants moved from nonindustrialized areas to other non-industrialized areas or from industrial areas

49. Foreman-Peck, "Insiders and Outsiders", in Guerin-Gonzales and Strikwerda, Politics of Immigrant Workers, pp. 336-344; Zolberg, "Labour Migration and Economic Regimes", in International Migration Systems, pp. 322-323.

50. Sidney Pollard, The Integration of the European Economy Since I8IS (London, I98I), p. 59.

5I. M.S. Anderson, The Rise of Modern Diplomacy, I450-I9I9 (London, I993), p. I93.

52. Timothy J. Hatton and Jeffrey G. Williamson, The Age of Mass Migration: Causes and Economic Impact (Oxford, 1998), pp. 32-52.

53. Centro de Estudios Puertorriquenos, Labor Migration under Capitalism: The Puerto Rican Experience (New York and London, 1979), pp. 21-22, cited in Shula Marks and Peter Richardson, "Introduction", in Marks and Richardson, International Labour Migration. See also Mary Kritz, "International Migration Patterns in the Caribbean Basin: An Overview", in Kritz, Keely, Tomasi, Global Trends in Migration. 


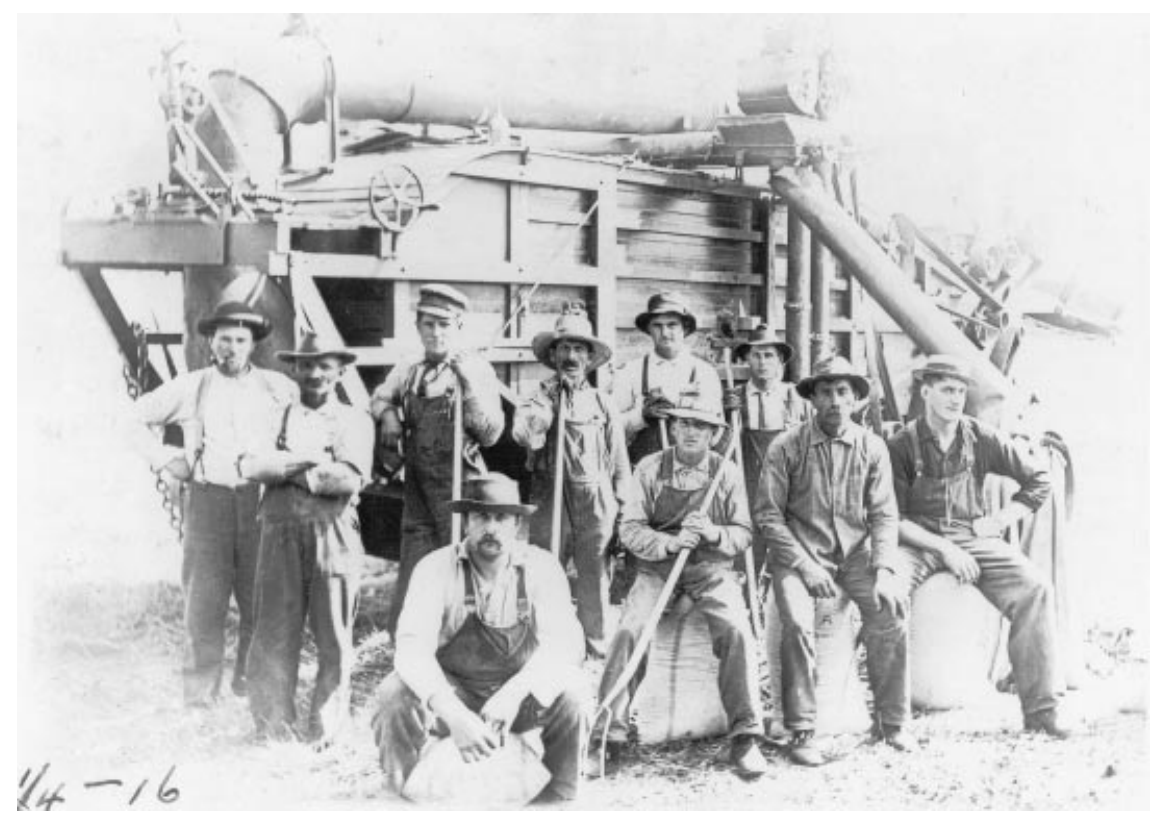

Figure 2. Czech threshing crew, I9I2, Montgomery, Minnesota. Mechanization of agriculture undercut peasant farming and created a larger wage labor market in the countryside, often of immigrants.

John Pesek Collection, Box 4, Immigration History Research Center, Minnesota

to non-industrialized ones. Agricultural Argentina experienced immigration, most of it from non-industrialized Italy and Spain, at an even higher rate than the industrializing United States. ${ }^{54}$ Britain was the most industrialized country in the world in the nineteenth century, yet it was also one of the greatest sources of out-migration. By the late nineteenth century, the large majority of migrants from Britain went, not to the United States, but to less industrialized countries such as Australia, New Zealand, and Canada where labor scarcity made for high wages. 55 The key to the nineteenth-century migration system was that its relative openness allowed potential migrants to weigh status, security, and wages and choose from a number of different possible countries of immigration. Nor is it true that migration largely meant low-wage, unskilled laborers moving into countries where they were exploited. Around 1900, approximately ten per cent of the foreigners in France were managers or owned their own businesses. ${ }^{56}$ In 1913, the sub-prefect of Briey in Lorraine

54. Carl Solberg, "Mass Migration in Argentina, I870-1970", in McNeill and Adams, Human Migration; Mörner, Adventurers and Proletarians, pp. 35-66.

55. Philip Taylor, The Distant Magnet: European Emigration to the USA (New York, 1972), p. 44. 56. Chambre des Deputés, Session de I90I, 2e séance du 27 juillet I9OI, p. 4. 
reported that even a French metallurgical firm such Marine-à-Homécourt recruited "a number of its engineers and the larger part of its foremen from the other side of the frontier" - Germany or Luxemburg. ${ }^{57}$ Just because the nearly global labor market worked as freely as it did, workers had more leverage to resist being recruited and exploited by employers. There are numerous cases of migrant workers brought into situations where their conditions or wages were worse than those of the normal labor market in the host country. But employers often tried and failed to pull in labor. In pre-World-War-I Europe, Poles usually refused to take jobs in France, and Flemings and Italians refused to replace the Poles in Germany. ${ }^{58}$

Most importantly, the picture of an increasingly nationalist European economy before I9I4 is misleading. The years before I9I4 were the last time the larger part of the globe formed a relatively open world economy, and it was not an economy which was doomed to collapse. Despite all the arguments for an increasingly global world being created today, in fact we are living in an international economy which is only barely more internationalized than that of the late nineteenth century. ${ }^{59}$ The level of direct foreign investment, that is, investment which carries some degree of control across borders, was almost certainly higher around 1900 than it was as late as the 1980 os. $^{60}$ As United States Federal Reserve Board Vice-Chairman Alan Blinder observed in March 1995:

To a significant extent, the industrialized nations of the world only recently reattained the levels of economic integration that they had reached at the eve of World War I. And a great deal of what we have been witnessing since 1950 is simply getting the world back to the level of integration that had been achieved in I9I4. ${ }^{61}$

In continental Europe, excluding continually protectionist Spain and Russia, tariffs in the late nineteenth century only rose from an average of 9.4 to 13.9 per cent. This was much lower than the twenty-five per cent reached after World War I. The percentage of wheat in world trade, for

57. Sous-préfet to Préfet, I9 juillet 1913, 4M 2192, Archives départmentales de Meurthe-et-Moselle, Nancy. Even relatively small numbers of skilled technicians could be extremely important in bringing in the most advanced techniques; see Claudius Riegler, "Labor Migration of Skilled Workers, Artisans, and Technicians and Technology Transfer between Sweden and Germany before World War I", in Hoerder, Labor Migration.

58. Abel Chatelain, Les migrants temporaires en France de I800 à I9I4 (2 vols) (Villeneuve d'Ascq, 1976), I: p. 236, 2: p. 69I; Dirk Hoerder, "Introduction to Labor Migration in the Atlantic Economies", in Hoerder, Labor Migration, p. 23.

59. Lee A. Craig and Douglas Fisher, The Integration of the European Economy, 1850-1913 (London, 1997), pp. 220-22I, 286. The following section draws on Carl Strikwerda, "The Troubled Origins of European Economic Integration", American Historical Review, 98 (1993), pp. IIO6-II42.

6o. Peter Svedberg, "The Portfolio-Direct Composition of Private Foreign Investment in I9I4 Revisited", Economic Journal, 88 (1978), pp. 763-767.

6r. Quoted in "Back to the Thrilling Trades of Yesteryear", New York Times, is March 1995, E5. 
example, was higher before I9I4 than it was to be until the 1980s. The only reason it is higher today is because of the European Union's massive subsidies for agricultural production. ${ }^{62}$ While historians have doubted that this internationalized economy could overcome the supposed rising tide of economic nationalism, Jeffrey Williamson and other economists demonstrate an impressive degree of convergence between economies. Migration raised wages as much as ten per cent in sending countries above what they would have been without migration. ${ }^{63}$ Just as capital and labor moved across the Atlantic, so they moved together among European countries. At the Frederick-Heinrich coal mine near Aachen, Germany, owned by the French firm Wendel, an observer noted, "Very few of the workers are Germans; one finds a mélange of Poles, Hungarians, Belgians, Dutch, Italians, and Swiss." ${ }^{64}$

Migration and the more open international world of which it was a part only flourished because governments supported it with monetary stability, financial interpenetration, virtually open borders, and legal near-equality for foreigners. The Latin Monetary Union put the French, Belgian, and Swiss francs at parity along with the Italian lira, while transactions between these currencies and the German mark were eased by their common calculation against the British pound and the cooperation among governments to support the gold standard. ${ }^{65}$ A whole range of international agreements abolishing tolls on international waterways, regulating global communications, standardizing weights, measures, and railway gauges, and creating health and safety laws on international shipping - provided a critical institutional foundation. Most historians have treated these agreements as products of the economic growth of the nineteenth century, but, as Craig Murphy argues, it is equally true that these agreements enabled economic growth to reach new levels. ${ }^{66}$ As a result, despite the increase in tariffs, the late nineteenth century saw international trade expand. ${ }^{67}$

People could also move relatively freely across borders because of one of those little-mentioned but enormously significant features of the late nineteenth century: there were almost no passports, and visa controls were

62. R.C. Michie, "The International Trade in Food and the City of London Since I850", Journal of European Economic History, 25 (1996), p. 37I.

63. Kevin O'Rourke, et al., "Mass Migration, Commodity Market Integration and Real Wage Convergence: The Late-Nineteenth Century Atlantic Economy", in Timothy J. Hatton and Jeffrey G. Williamson (eds), Migration and the International Labor Market, I850-I939 (London, 1994). 64. Victor Cambon, Les derniers progrès de l'Allemagne (Paris, 1914), p. 25.

65. Guilio Gallarotti, The Anatomy of an International Monetary Regime: The Classical Gold Standard, 1880-19I4 (New York, 1995), pp. 227-235. For background on the international financial sector of the period, Rondo Cameron, "Introduction", in Rondo Cameron and V.I. Bovykin (eds), International Banking, I870-1914 (New York, 199I); Y. Cassis (ed.), Finance and Financiers in European History, I880-I960 (Cambridge, 1992).

66. Craig Murphy, International Organization and Industrial Change: Global Governance since 1850

(Oxford, 1994), pp. 55-135.

67. Ibid., pp. 46-8I. 
astonishingly lax by twentieth-century standards. ${ }^{68}$ Thousands of Belgians, Italians, and Spaniards immigrated to France by simply walking in. In the Luxemburg-French-German border regions, workers of a wide range of nationalities floated back and forth looking for higher wages or better working conditions. Some even lived in one country and worked every day in another, with only minimal governmental supervision. ${ }^{69}$ Once in these countries, foreigners enjoyed many of the same rights to engage in business as citizens, rights which in many cases foreigners in Europe are just beginning to enjoy again to the same extent in the I990s.

The anti-immigrant feeling before World War I is not surprising. The failure of this feeling to translate into state action is more surprising. Besides the racist controls against Asians, most immigrant countries continued to be open to migrants. The support of employers, immigrant and secondgeneration citizens, and other interest groups in favor of open borders overcame nativist opposition. ${ }^{70}$ In Europe, the French government tried to placate anti-immigrant feeling with small restrictions, but the demand for labor was so strong that industrialists and large agricultural landlords would not permit effective controls. Germany's restrictions against Polish migration are the exception which proves the rule. In eastern Germany, the flow of German citizens, both German and Polish speakers, to the Ruhr in the west meant that large agricultural landlords came to depend increasingly on Polish and Ukrainian workers from Russia. The Germans tried to recruit laborers from their ally Austria-Hungary, but landlords and the government in Austria-Hungary protested because migration to Germany drove up the price of agricultural labor. Meanwhile, Germany had to compete with France for Italian workers, at the same time as Denmark, Sweden, and Switzerland all sought to lure eastern European laborers away from German and Austrian-Hungarian employers. Thus, even as German officials and nationalists wanted to restrict migration, farmers and big business combined to keep the country more dependent on it. By 19I4, Germany probably had the largest immigrant population in Europe, and one of the largest in the world. ${ }^{71}$ Only the decisive act of the German government in declaring war

68. John Torpey, The Invention of the Passport: Surveillance, Citizenship, and the State (Cambridge, 1999); Stephen Kern, The Culture of Time and Space, I880-1918 (Cambridge, MA, I983), p. 194; Richard Plender, International Migration Law 2nd ed. (Dordrecht, 1988).

69. Carl Strikwerda, "France and the Belgian Immigration of the Nineteenth Century", in Guerin-Gonzales and Strikwerda, Politics of Immigrant Workers, pp. II4-I2I; idem "The Troubled Origins of European Economic Integration: International Iron and Steel and Labor Migration in the Era of World War I", American Historical Review, 98 (1993), pp. II2O-II23.

70. Foreman-Peck, "Insiders and Outsiders", in Guerin-Gonzales and Strikwerda, Politics of Immigrant Workers, pp. 308-315.

7I. Lars Olsson, "Labor Migration as a Prelude to World War I", International Migration Review, 30 (1996), pp. 875-900; Klaus Bade, "'Billig und Willig' - die 'ausländischen Wanderarbeiter' im kaiserlichen Deutschland", in Bade (ed.), Deutsche im Ausland-Fremde in Deutschland: Migration in Geschichte und Gegenwart (Munich, 1992), pp. 3II-320; George Nellemann, "Schwedische und Polnische Gastarbeiter in der dänische Landwirtschaft”, Migration, 20 (1993/94), pp. 85-95. 
in August I9I4 destroyed the migration system which had developed over decades.

In short, the lesson of the nineteenth-century migration system is that states created it or allowed it to happen. They also always had the power to end it, and they eventually did. Migration took place within an international regime of relative cooperation which states created, but they always held the upper hand. What is striking about the nineteenth-century system is not that anti-immigrant feeling existed, but that states by and large acted against immigrants as little as they did and upheld an open international economy despite political pressures to curtail it. It is indicative that it took a world war to end the migration system of the nineteenth century. The problem of the late nineteenth century, then, is not that all trends were moving in the direction of protectionism and a restriction of international ties. Instead, two powerful forces were at work, one making for increased economic integration and, possibly, further internationalism, the other making for higher tariffs, restrictions on migration, and, frequently, conservative nationalism and international conflict. The decisions by Germany, Austria-Hungary, and Russia to go to war in 1914 were partly aimed at the whole web of international ties of which migration was a critical part. While this violent solution to the complexities of an international system was not an inevitable result of the way the nineteenth-century social and economic system had developed, it does demonstrate the enormous pressures which the system had unleashed. The results of the First World War also show how profound and enduring the consequences of rejecting a more open international system can be. ${ }^{72}$

\section{THE GREAT WAR AND ITS AFTERMATH}

The First World War marks a decisive break in the history of migration as it does in world history. The war destroyed the international regime of the nineteenth century while the nationalism and ideological conflict resulting from the war prevented any new international regime from emerging. ${ }^{73}$ As the classicist and international activist, Gilbert Murray, wrote in I92I, in disbelief, "Things are done now, in time of peace, which would been

72. Carl Strikwerda, "Capitalists, Immigrants, and Populists: The Impact of Social Conflict and the State on the Origins of World War I", in Michael Hanagan, Leslie Page Moch, and Wayne te Brake (eds), Challenging Authority: The Historical Study of Contentious Politics (Minneapolis, MN, I998), pp. 213-227; Carl Strikwerda, "Reinterpreting the History of European Integration: Business, Labor, and Social Citizenship in Twentieth-Century Europe”, in Jytte Klausen and Louise Tilly (eds), European Integration in Social and Historical Perspective, I850 to the Present (Lanham, MD, 1997).

73. The following section draws on Strikwerda, "Reinterpreting the History of European Integration", in Klausen and Tilly, European Integration, pp. 6I-66. 
inconceivable before 19I4. ${ }^{74}$ Abruptly, during World War I, European and American governments sequestered the property of foreigners, imposed passport and visa controls, and introduced or restricted the issuance of work permits. Britain introduced an Aliens Act in 1914, which remained in effect after the war. ${ }^{75}$ As the International Labour Office noted, "During the war the possession of a passport issued by the national authorities, with a visa of the representatives of the country to which the traveller intended to go, became compulsory for all international travelling. ${ }^{76}$ In 1916, the French government created an identity card which had to be carried by all of the new immigrant workers who had come to the country to work because of the wartime labor shortage. The following year, the card was imposed on all foreigners. Not until the I950s did French workers who were citizens have to carry a card. ${ }^{77}$ Even Germany, which had set a precedent for regulating foreign workers through its pre-World-War-I restrictions on the Poles, made major changes as a result of the war. ${ }^{78}$ For the first time, the law established the principle that foreigners were now to be recruited only after no native workers could be found. ${ }^{79}$ As Ulrich Herbert writes, this has "ever since served as one of the foundations of German policy toward foreigners, up to the present day". ${ }^{80}$ In Germany, "immigrant" (Einwanderer), too, became legally redefined. It was no longer the "foreign" worker or businessperson residing in Germany who sought to become a German citizen, but the ethnic German from other countries who wished to "return" to Germany. All foreign workers now had to have cards or be deported.$^{8 \mathrm{I}}$ The requirement of a visa or an identity card became the lever which operated the restrictive mechanisms which many countries imposed on foreign workers. Workers who were recruited through official labor agencies and who followed regulations once they were working in the host country obtained visas or cards. Those who were not recruited officially or who did not follow regulations did not receive visas and thus were vulnerable to expulsion. The net effect of the regulations imposed on immigrant workers was that they became a special category of laborer within the nation's workforce. As Eugene Kulischer wrote, the foreign worker became a "modern coolie",

74. Gilbert Murray, The Problems of Foreign Policy (London, 192I), p. vii.

75. John W. Brown, World Migration and Labour (Amsterdam, 1926), p. 22I.

76. International Labour Office, Emigration and Immigration: Legislation and Treaties (Geneva, I922), p. 163.

77. Patrick Fridenson, "Introduction", in Fridenson (ed.), The French Home Front 19I4-19I8 (Oxford, 1992), p. 7.

78. Ulrich Herbert, A History of Foreign Labor in Germany, I880-1980 (Ann Arbor, MI, 1984), pp. $285-304$.

79. Klaus Bade, "Labour, Migration and the State", in Bade (ed.), Population, Labour, and Migration in 19th and 20th Century Germany (New York, 1987), p. 8I.

80. Herbert, History of Foreign Labor, p. I25.

81. International Labour Office, Emigration and Immigration, p. 242. 
allowed into the country for a specific amount of time under special regulations. ${ }^{82}$

As Avner Offer has argued, the crucial role played by the British dominions in the Allied victory gave racist labor attitudes an important place. One-third of the "British" forces in the final offensives in I9I8 which broke the German army were in fact Australian, Canadian, New Zealander, and white South African troops. A very large part of the grain which kept Britain alive in the dismal months of 1917 came from the dominions. One of the key demands of these countries of the British Empire at Versailles was racial exclusion. One of the critical ways in which these leaders influenced the Versailles peace settlement and the League of Nations was the blunting of Japanese, Chinese, and Indian demands for the free movement of labor and the end of racial exclusion. ${ }^{83}$

The clearest evidence for the importance of the state in determining migration is the effect of new government policy on the tides of labor migration. The US Immigration Act of 1924, the so-called Quotas Act, drastically curtailed immigration from Italy and eastern Europe and greatly weakened the ability of these societies to deal with their unemployment. ${ }^{84}$ In the early I920s, before the Quotas Act went into effect in I925, immigration into the United States from southern and eastern Europe soared from the depressed levels created by World War I, jumping from I59,000 a year to 580 ,000. The Quotas Act slashed this to only 20,247. ${ }^{85}$ Some European nations experienced an increase in immigration, but the change in the way migration was treated is of greater importance. Belgium became an important country of in-migration for the first time; France became the most important importer of labor in the world. The change in the French situation from before the Great War is particularly striking. Before I9I4, migrants came with almost no official controls. In the I920s, French immigration was strictly controlled by nation-to-nation agreements - for example, between Mussolini's Italy and France. ${ }^{86}$

The destruction of much of the economic integration of the pre-19I4 era meant that the underlying economic and institutional support for

82. Eugene Kulischer, Europe on the Move: War and Population Changes, I9I7-I947 (New York, 1948), p. 25 I.

83. Avner Offer, The First World War: An Agrarian Interpretation (Oxford, 1989), pp. I64-214, 37I-376.

84. Michael C. Lemay, From Open Door to Dutch Door: An Analysis of United States Immigration Policy Since 1820 (New York, 1987), pp. 54-57, 82-86; Higham, Strangers in the Land, pp. 300324.

85. H.A. Gemery, "Immigrants and Emigrants: International Migration and the US Labor Market in the Great Depression", in Hatton and Williamson (eds), Migration and the International Labor Market, p. I8o.

86. Cross, Immigrant Workers, pp. 174-I88; Donald Reid, "The Politics of Immigrant Workers in Twentieth Century France", in Guerin-Gonzales and Strikwerda, Politics of Immigrant Workers, pp. 267-269. 
relatively free migration was gone. Whereas international trade and foreign investment had expanded with migration before 1914, all three shrank in the interwar era. The collapse of the gold standard and international financial cooperation meant, too, that one of the crucial sinews of the nineteenthcentury economic expansion was gone. ${ }^{87}$ As a telling sign of the explosion of nationalism caused by the Great War, one-third of the international organizations created in the late nineteenth century disappeared during the hostilities and their aftermath. ${ }^{88}$ Significantly, the International Labour Office, an organ of the League of Nations, bowed to the opposition of governments and declined to touch migration. Instead, the International Federation of Trade Unions, which represented workers' organizations, tried but failed to create an International Office on Migration. ${ }^{89}$ Most European societies redefined themselves in a more nationalistic fashion. The expansion of social welfare legislation was a great victory for most working people, but almost every country had provisions discriminating against foreigners in this legislation. Only French citizens could vote or be a delegate in the newlycreated mine safety councils, even in mines where only five per cent of the workers were French. ${ }^{\circ}$

The movement for European integration after the Second World War is usually seen as a reversal of the nationalism of the late nineteenth century and the interwar era. From a long-term historical perspective what is striking is the limited liberalization and integration which actually occurred, and, thus, the limited degree of migration which resulted. The process of European integration did not undo the legal tradition which was created by the First World War and strengthened by the Great Depression. ${ }^{91}$ The European Community of the I970s and 1980s, in other words, was only a very partial return to the more international open regime of the pre-I9I4 era. After 1945, the question was whether western Europe would be connected only by trade relations, or in addition by a web of multinational relations as before 19I4. The European governments chose trade, and restricted other forms of relationships such as multinational business and migration. Once again, it was states which determined the tides of migration. ${ }^{92}$ The European Coal and Steel Community followed the pre-I9I4 system of free trade in allowing iron and coal to move across borders, but otherwise governments

87. Svedburg, "Portfolio-Direct Composition", pp. 776-777; Barry Eichengreen and Douglas Irwin, "Trade Blocs, Currency Blocs, and the Reorientation of World Trade in the I930s", Journal of International Economics, 38 (I995), pp. I-24.

88. Murphy, International Organization, p. 82.

89. Brown, World Migration and Labour, pp. 27I-272.

90. Reid, "Politics of Immigrant Workers", in Guerin-Gonzales and Strikwerda, Politics of Immigrant Workers, p. 266.

91. Josef Kunz, The Changing Law of Nations (Columbus, OH, 1968), p. 9.

92. Alan Milward and Vibeke Sorenson, "Interdependence or Integration? A National Choice", in Milward, et al., The Frontier of National Sovereignty: History and Theory 1945-I9g2 (London, 1993). 
took over the model set by the interwar cartels in regulating prices and restricting foreign investments. ${ }^{93}$ Most important, "the Coal and Steel Community did not open new outlets for migrants". ${ }^{94}$ France allowed foreign coal and steel workers to come in only if their hiring was justified by employers, and even then these workers could not move their residence or place of employment freely. ${ }^{95}$ Even Britain, which had a longer tradition of liberal state policies and was not part of European economic integration, adopted state control over foreigners in the labor market for the first time although Irish workers were still allowed to immigrate freely. ${ }^{96}$ Just as the Coal and Steel Community and Common Market drew heavily on the legacy of the interwar cartels, so the guestworker recruitment of the I950s through the early I970s was closely patterned after the state-to-state labor migration system of the $1920{ }^{97}{ }^{97}$ The Common Market eliminated the preference for nationals over foreigners from within the Community and the requirement for these foreign workers to have work permits, but workers were guaranteed residence only if they had a job; migration to seek employment was still restricted and regulated. Workers could only move with complete freedom to another state if they already had a job offer. ${ }^{98}$ Today, unemployed workers in the Community still usually have only ninety days in which to look for work in another state. ${ }^{99}$ Only in the 1990 s did the European Court of Justice rule that European migrant workers' pension rights were protected if they worked in more than one country and that discrimination against non-European workers who were legally employed within the Community was illegal. ${ }^{100}$ As Elizabeth Meehan has argued, migration, just as before 19I4, is today often a key to determining whether a genuine movement toward a more global society exists. ${ }^{\text {Ior }}$

\section{NEW OR OLD ORDER?}

In the contemporary era of globalization, how much of the pre-I9I4 system of migration might return? Even as population growth in the less developed

93. Jean-Paul Couthéoux, "Les pouvoirs économiques et sociaux dans un secteur industriel: La sidérurgie”, Revue d'histoire économique et sociale, 38 (1960), p. 364.

94. Federico Romero, "Migration as an Issue in European Interdependence and Integration: The Case of Italy", in Milward, et al., Frontier of National Sovereignty, p. I35.

95. Alphonse Romeu-Poblet, Le régime juridique des étrangers en France (Angouleme, 196I), pp. 80-8I.

96. Diana Kay and Rob Miles, Refugees or Migrants? European Volunteer Workers in Britain, I946I95I (London, I992), pp. I6I-I62.

97. Dennis Swann, The Economics of the Common Market (London, I988), pp. I3I-I68; Alan Milward, The European Rescue of the Nation-State (Cambridge, I992), pp. I-45.

98. Anthony Bouscaren, European Economic Community Migrations (The Hague, I969), pp. II-I3. 99. James Hollifield, Immigrants, Markets, and States (Cambridge, 1992), p. 259.

Ioo. "Free Movement of Foreign Workers", Frontier-Free Europe, 8 (1994), p. 2.

IOI. Elizabeth Meehan, Citizenship and the European Community (London, I993), pp. 78-IOO. 
countries has slowed, a huge disparity will persist for decades between less developed nations' underemployed populations and the demand for labor in the industrial world. One German research institute has in fact estimated that the European Union as a whole may need an immigration of 900,000 people a year by the year 2020 to offset the decline in its workforce because of low fertility and an ageing population. ${ }^{\mathrm{IO} 2}$ Meanwhile, even the limited amount of migration to the developed world which is allowed to exist at present has a huge impact on poorer countries which export labor. Just as in nineteenth-century Europe, remittances, the acquisition of skills and information, and a partial alleviation of population pressure for a period are all-important effects of migration on poorer nations in Africa, Asia, and Latin America. In 1989 the World Bank found seventeen countries where migrant workers' remittances accounted for at least three per cent of GDP. Total remittances were estimated to be $\$ 65.6$ billion, second only to oil as a commodity in international trade. ${ }^{\mathrm{IO} 3}$

As in the nineteenth century, however, streams of migration will continue to flow in ways beyond simply those from less developed to industrialized countries. Few observers in the I950s would have predicted that, by the I970s and I980s, Pakistanis and South Koreans would be working in the Persian Gulf states, that Nigeria, the Ivory Coast, and Argentina would be magnets for migration from nearby low-income countries, or that the communist bloc would be bringing Algerians to East Germany and North Koreans and Bulgarians to Russia. ${ }^{104}$ Non-Western societies that Western observers have long thought of only as sources of emigrants have themselves become homes for migrants. While Egypt continued in the 1980s to send workers and professionals to other Arab countries such as the oil sheikdoms, west Africans began taking jobs in Egypt. ${ }^{105}$ In the 1990s, in a stunning reversal of colonialism, British workers even migrated to work for Chinese employers in Hong Kong. ${ }^{\text {Io }}$

I02. "Study: Germany Needs I2.5 Million, Europe 28 Million Immigrants By 2020", German Information Service, I7 December 1993, p. 5. With continued unemployment, it is not clear that these estimates would hold.

I03. Sharon Stanton Russell and Michael S. Teitelbaum, International Migration and International Trade (Washington DC, 1992), pp. 28-53.

I04. Böhning, "Statistical Survey of Economically Active Foreigners", in Bohning, Studies in International Labour Migration; L. Huan-Ming Ling, "East Asian Migration to the Middle East: Causes, Consequences, and Constraints", International Migration Review, I8 (1984), pp. 19-36; Nasra Shah, "Pakistani Workers in the Middle East", International Migration Review, I7 (1983), pp. 410-424; Solberg, "Mass Migration in Argentina", in McNeill and Adams, Human Migration, p. I6I; Adriana Marshall, "Structural Trends in International Labor Migration: The Southern Cone of Latin America", in Kritz, Keely, and Tomasi, Global Trends in Migration; Morner, Adventurers and Proletarians, p. III; Carrère d'Encausse, Decline of an Empire, p. II6.

I05. Ralph Sell, "Egyptian International Labor Migration and Social Processes toward Regional Integration”, International Migration Review, 22 (1988).

106. Edward A. Gargan, "Sign of a Last-Gasp Empire: British are the Coolies", New York Times, I6 October 1996, A4. 


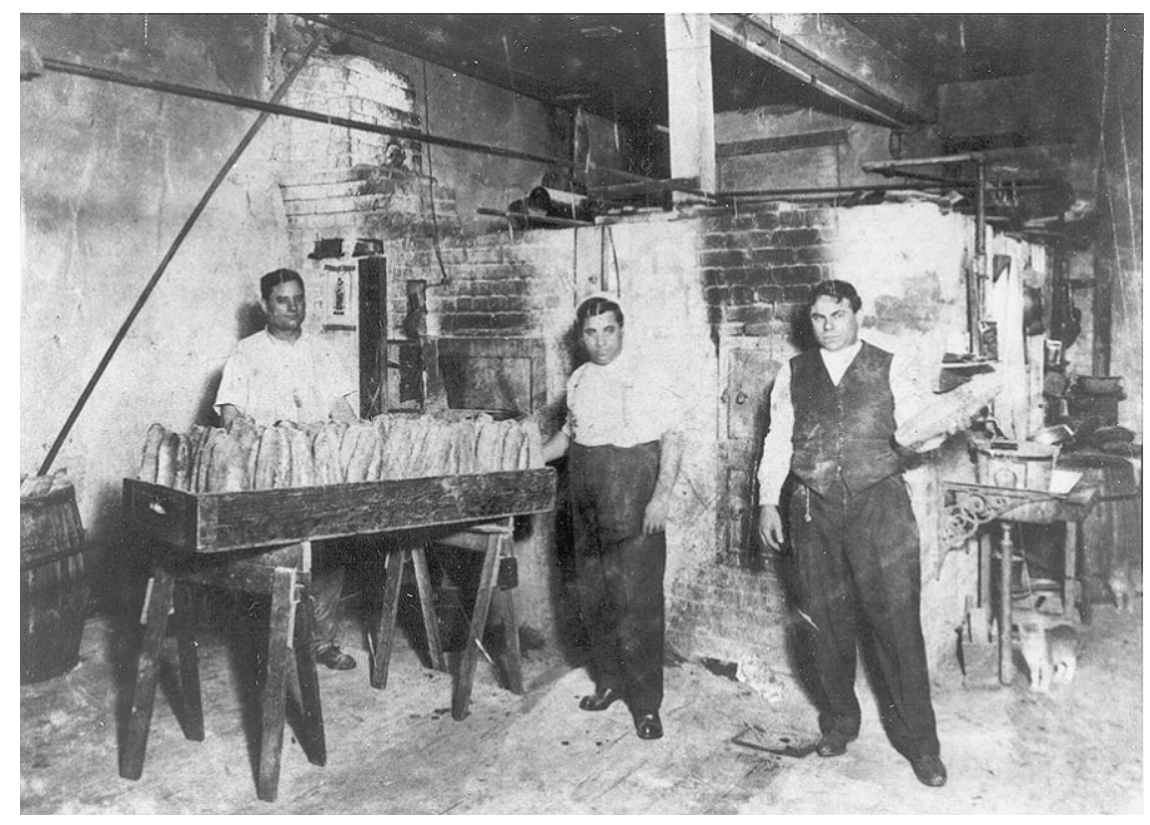

Figure 3. Marselie's bakery (Italian), 1910. Communities of immigrant labor eventually created their own opportunities for small business people.

AIHA Stella Del Nord Collection, Box 4, Immigration History Research Center, Minnesota

As was true for countries such as Germany and Italy a century ago, it is often less developed countries which are experiencing rapid industrialization which generate high levels of emigration. ${ }^{\text {107 }}$ Although these economies as a whole have growing employment or output, many workers are losing their traditional occupations or experiencing their first taste of modern life through the very process of economic change. Traditional economic sectors can decline more quickly than modern economic sectors can provide numerous, well-paying jobs. In many cases, these workers prefer to take their chances on a better life in a more developed society than to settle for taking a more difficult job in their own country. ${ }^{108}$

Yet, on balance, the differences between the pre-I9I4 system and the

I07. Sassen, Mobility of Labor and Capital, pp. I4-20. This section draws on Strikwerda and Guerin-Gonzales, "Labor, Migration, and Politics", in Guerin-Gonzales and Strikwerda, Politics of Immigrant Workers, pp. 7-II, 38-39.

I08. Augustin Escobar, Mercedes Gonzalez, and Bryan Roberts, "Migration, Labour Markets, and the International Economy: Jalisco, Mexico, and the United States", in Jeremy Eades (ed.), Migrants, Workers, and the Social Order (London and New York, 1986), pp. 46-47; Peter Fischer, Reiner Martin, and Thomas Straubhaar, "Interdependencies between Development and Migration", in Tomas Hammar, et al. (eds), International Migration, Immobility, and Development: Multidisciplinary Perspectives (New York, 1997), pp. 94-96. 
future which is evolving today are more profound. The lesson of the nineteenth century is certainly the immense power of the state, and states' policies have changed so fundamentally that a free-flowing global labor market is unlikely to re-emerge. Globalization in investment and trade may continue to expand in a revolutionary fashion, but a global labor market will almost certainly not emerge. In contrast to theorists such as Piore, who argue that migration in the contemporary world economy is largely determined by the need of capitalist economies for labor, the evidence better supports the argument of W.R. Böhning that governments have enormous power to decide whether and how migrants will come. As Böhning puts it, "Demand, then, is caused economically, screened politically, and given effect to administratively." ${ }^{\text {"og }}$ Even Saskia Sassen, who argues that state sovereignty is being transformed by globalization at the end of the twentieth century, admits that immigration is the one area where states have retained the greatest amount of control. ${ }^{\text {Iо }}$ We are moving into an international regime of relative peace and globalized trade and finance, largely led by the United States and a re-energized Europe, but it one in which nation states will continue to resist giving up control of labor migration.

States will continue to retain control over migration, albeit at high costs, and thereby counteract or offset economic pressure. Many observers have pointed to an increase in the number of foreigners in those countries after France and Germany imposed severe restrictions on the immigration of guestworkers in the early I970s to argue that state controls are futile. But the controls in fact have had a major effect. The increase in the number of foreigners has been largely fueled by family reunification, which state policies allowed, while France managed to reduce the proportion of foreigners and Germany slowed the rate of increase from what it had been in the 1960s and 1970s. As a percentage of the labor force in France, immigrants fell over forty per cent from the early I970s to the late 1980s, while the percentage of foreigners between 1982 and 1992 went from 6.8 to 6.3 in France and from 7.6 to 8.4 in Germany. ${ }^{\text {III }}$ Similarly, labor scarcity and an industrializing economy have only recently begun to weaken the Japanese government's controls on immigration. Instead, by using subsidies and tax advantages, the government, for a long period, encouraged some laborintensive enterprises to continue to use "high-cost" Japanese workers rather than import foreign labor at lower wages. At the same time, other employers have been encouraged to become less labor-intensive, in part again, to avoid the temptation to import labor. The result presents a striking counterexample

I09. Böhning, Studies, p. I40.

IIo. Sassen, Losing Control?, pp. 59-99.

III. Philip E. Ogden, "Labour Migration to France", in Cohen, Cambridge Survey of World Migration, p. 294; Heinz Fassmann and Rainer Munz, "Patterns and Trends of International Migration in Western Europe", in Fassmann and Munz (eds), European Migration in the Late Twentieth Century (Aldershot, 1994), pp. 6-9. The percentage of foreigners in Germany had gone from 4.9 in $1970 / 71$ to 7.6 in 1982 . 
to those who argue that industrialization and economic growth always bring about immigration. Despite being one of the fastest-growing and most industrialized economies in the world for over forty years, Japan until very recently had remarkably little immigration. Ironically, as Japan sunk into recession in the 1990s, an ageing population and young people's disdain for low-status work has finally led to increased immigration, although still at a low level by comparison with other industrialized countries. ${ }^{\text {II2 }}$

The same power of the state to shape immigration can also be seen in the case of countries that choose the opposite route and become overwhelmingly dependent on foreign labor. The Arab states around the Persian Gulf, while recruiting workers during the oil boom of the I970s and early 1980s, deliberately shifted their recruitment, first from the non-oil Arab states - Egypt, Yemen, and Syria - to south Asia - India, Pakistan, and Bangladesh - and finally to east Asia - South Korea and Taiwan. The Arabs from the non-oil states, despite their being closer geographically and culturally, proved more dangerous because of the threat that they would stay permanently and bring into the Gulf states conflicts between Sunnis and Shi' ites and between conservatives and radicals. The south Asians could be controlled more easily and given less opportunity to stay, but eventually posed the threat of labor militancy. The east Asians, finally, were brought in on a strictly contract basis, to finish a project and then be shipped out by their employers. These changes also coincided with the changing employment needs of the Gulf states for more skilled, "targeted" labor. Nonetheless, the changing economic needs for labor were combined with careful attempts by the governments to balance political threats and security interests. ${ }^{\mathrm{II} 3}$

The role of the state can be critical, too, even in determining whether immigrant workers strengthen or undermine labor solidarity. Although there is a widespread assumption that the presence of immigrants necessarily weakens the ability of native workers to organize, in fact it seems that the state plays a major role in repressing or encouraging immigrant and native workers to unite. In the most widely-known work on immigrant workers in contemporary western Europe, Stephen Castles and Godula Kosack argue that "immigration is advantageous to the employers, through its effect in weakening the labour movement and in dividing the working class" ${ }^{\mathrm{II}}{ }^{4}$ Yet

II2. Edward Ruebens, "Low-level Work in Japan without Foreign Workers", International Migration Review, I5 (198I), pp. 749-757; James Sterngold, "Japan Is Divided on Foreign Workers", New York Times, I7 December 1989, B3.

II3. Vaughn Robinson, "Bridging the Gulf: The Economic Significance of South Asian Migration to and from the Mideast", in Russell King (ed.), Return Migration and Regional Economic Problems (London, 1986); Zafer H. Ecevit, "International Labor Migration in the Middle East and North Africa: Trends, Effects, and Policies", in Kritz, Keely, and Tomasi, Global Trends in Migration; Roger Ballard, "The Political Economy of Migration: Pakistan, Britain, and the Middle East", in Eades, Migrants, Workers, and the Social Order.

II4. Stephen Castles and Godula Kosack, Immigrant Workers and the Class Structure in Western Europe, 2nd ed. (Oxford, 1985), pp. 28-45, 428-429. 
with large and approximately equal numbers of foreign workers, Germany and France possess markedly different wage levels and union movements. The role of the state appears to be a critical variable. In five of Castles' and Kosack's twelve examples of repression of immigrant workers in Europe in the 1970s, governments acted against immigrant workers, while in none of the cases did they intervene on the behalf of immigrants. ${ }^{\text {II }}$ There is little evidence, furthermore, that guestworkers in western Europe have served as a "reserve army of the unemployed". Some of them have reasonably good jobs, and the number of unemployed among them is not exceptionally high. ${ }^{116}$ The contrast between the high rate of union organization among Turks and Italians in Germany and their disorganization in Switzerland, Barbara Schmitter argues, can only be accounted for by the decisive role that the state and unions have played in Germany. ${ }^{\text {II7 }}$

Barring a global depression, the world economy will continue to encourage migration and states will attempt to regulate, control, and channel migrants. The potential for migration to contribute to greater economic development is clear, but the resistance to migration is at least equally imbedded in history. We can see, too, the long persistence of policies and even the effects of policies well after the circumstances of their origin are past. Globalization will probably mean only a slight increase in the ease with which workers can move between societies. As David Henderson writes,

A world of closed borders can be viewed as a world of unexploited opportunities; greater freedom of movement would in itself contribute to international prosperity; and the gains thus arising would be widely shared, by recipient countries and countries of origin alike. Judged in this light, "economic migrants" have a clearly positive role. But general prosperity is only one aspect of the matter, and not necessarily the most important. It is likely that in relation to issues of cross-border migration, far from having reached the "end of history", the world is now entering a new and more difficult phase. ${ }^{\text {II8 }}$

II5. Ibid., pp. I52-179. It is striking that the strongest statements on immigrants' effect on labor solidarity come in Castles and Kosack's introduction and conclusion, as in the previous footnote. The language in chapter 4 on "Trade Union Policies and Industrial Disputes", pp. II6-I79, is more cautious. My criticisms of their work on labor should not be extended to their treatment of discrimination against immigrants in housing and social welfare.

II6. Constance Lever-Tracy, "Immigrant Workers and Postwar Capitalism: In Reserve or Core Troops in the Front-Lines?", Politics and Society, I2 (1983), pp. 132-42.

II7. Barbara Schmitter, "Trade Unions and Immigration Policies in West Germany and Switzerland", Politics and Society, Io (I98I), pp. 317-334.

II8. Henderson, "International Economic Integration", p. 652. 